\title{
Inhibitory Effects of Somatostatin on Rat Hepatocyte Proliferation Are Mediated by Cyclic AMP ${ }^{1,2}$
}

\author{
Norihiro Kokudo, M.D., Piyush C. Kothary, M.S., Frederic E. Eckhauser, M.D., and Steven E. Raper, M.D. \\ Department of Surgery, University of Michigan Medical Center, Ann Arbor, Michigan 48109
}

Submitted for publication November 19, 1990

Somatostatin (SS-14) is known as an antigrowth factor for a variety of cell types, including gastrointestinal mucosa, exocrine pancreas, lymphocytes, and some tumors. We have recently identified and biochemically characterized SS-14-binding protein on rat liver plasma membranes (S. E. Raper, P. C. Kothary, and J. DelValle, Gastroenterology 96: A408, 1989; P. C. Kothary et al., Digestion 46(Suppl 1): 58, 1990). We hypothesized that SS-14 may affect liver growth as well and investigated cellular mechanisms of this phenomenon focusing on the second messenger cAMP. Freshly isolated rat hepatocytes were plated on tissue culture dishes coated with Matrigel (laminin, heparan sulfate, and type IV collagen). The medium was not supplemented with serum or hormones. Either dibutyryl-cAMP (1 $\mathrm{mM}$ ) or isobutylmethylxanthine (IBMX, 0.1 $\mathrm{m} M$ ) was added in the presence or absence of SS-14 (10 $\mathrm{nM})$. DNA synthesis was estimated by the rate of $\left[{ }^{\mathbf{3}} \mathrm{H}\right]$ thymidine incorporation into DNA and by the labeling index (an autoradiographic measurement of the number of labeled nuclei). SS-14 significantly inhibited both $\left[{ }^{3} \mathrm{H}\right]$ thymidine incorporation and labeling index of rat hepatocytes stimulated by dibutyryl-cAMP or IBMX. SS-14 also inhibited intracellular cAMP accumulation stimulated by IBMX. We conclude that SS-14 exerts at least part of its antiproliferative effects via the adenylate cyclase system. Further study using other signal transduction systems may yield more information about mechanisms of hepatocyte growth. @1991 Academic Press, Inc.

\section{INTRODUCTION}

Somatostatin (SS-14) is a tetradecapeptide first isolated from the hypothalamus on the basis of its ability to inhibit growth hormone secretion by rat anterior pituitary cells in culture [1]. Subsequently SS-14 has been documented to exert antigrowth effects on a variety of

\footnotetext{
${ }^{1}$ Presented at the Annual Meeting of the Association for Academic Surgery, Houston, TX, November 14-17, 1990.

2 This work was supported by NIH Grant 1 R29 DK42485-01.
}

cell types such as gastrointestinal mucosa [2], exocrine pancreas [3], lymphocytes [4], and some tumors [5, 6]. Its long-acting analogue (SMS 201-995) has been tried in the treatment of gut endocrine tumors with some response [7]. We have recently identified and biochemically characterized an SS-14 binding protein on rat liver plasma membranes $[8,9]$. The presence of SS-14 binding protein in the liver has also been confirmed by studies demonstrating hepatic uptake of intraportally injected ${ }^{125} \mathrm{I}-\left[\mathrm{Tyr}^{11}\right]$-SS-14 in a manner partially blocked by excess unlabeled SS-14 [10]. These results led us to hypothesize that SS-14 may affect liver growth as well. There have been several reports documenting the inhibitory effects of SS-14 on liver growth [11, 12]. However, little is known about the cellular mechanisms of this antiproliferative effect.

In previous studies using other cell types, SS-14 has heen shown to inhibit various cellular events by attenuating the production of cellular cyclic AMP (cAMP), an effect that seems to be mediated via pertussis toxinsensitive inhibitory guanine nucleotide-binding proteins $[13,14]$. A number of physiological findings, using cAMP analogues such as dibutyryl-cAMP (db-cAMP), suggests that attenuation of cAMP production is not sufficient to serve as the only signal for eliciting this kind of inhibition [15, 16]. Using primary cultures of adult rat hepatocytes, we investigated the cellular mechanisms of the antiproliferative effect of SS-14 focusing on the adenylate cyclase system.

\section{MATERIALS AND METHODS}

\section{Materials}

Synthetic somatostatin-14 was purchased from Peninsula Laboratories, Inc. (Belmont, CA). Dibutyryl-cyclic AMP, 3-isobutyl-1-methyl-xanthine (IBMX), and collagenase (type I) were from Sigma Chemical Co. (St. Louis, MO). Matrigel and Dispase were obtained from Collaborative Research, Inc. (Bedford, MA).

\section{Hepatocyte Isolation}

Sprague-Dawley male rat (250-275 g) hepatocytes were isolated using a two-step collagenase perfusion 


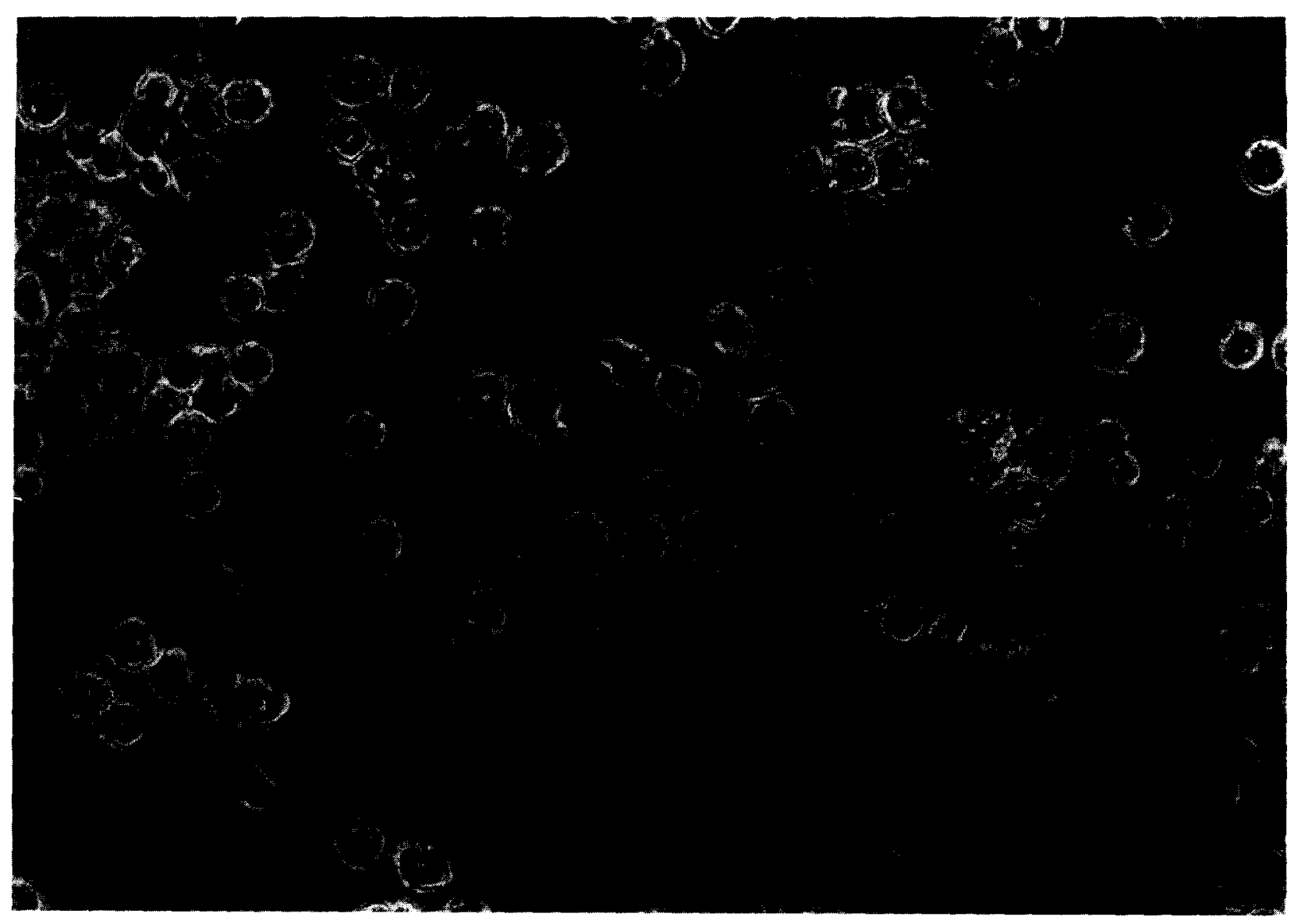

FIG. 1. Phase-contrast microscopy of rat hepatocytes cultured for $48 \mathrm{hr}$ on Matrigel in presence of IBMX $(0.1 \mathrm{mM}, 24 \mathrm{hr})(\times 200)$.

technique $[17,18]$. Briefly, rat liver was perfused for 10 min with $\mathrm{Mg}^{2+} / \mathrm{Ca}^{2+}$ free Hank's buffer at $37^{\circ} \mathrm{C}$ followed by 8-10 min with Eagle's minimum essential medium (MEM) with $0.05 \%$ collagenase (type I). The liver was excised and placed in petri dish containing fresh MEM with collagenase. The liver capsule was stripped and cells were released by gentle manipulation. The resulting crude preparation was filtered through 250 and 100 $\mu \mathrm{m}$ nylon mesh and collagenase was inactivated with 0.5 $\mathrm{ml}$ of fetal calf serum (FCS). Centrifugal separation was employed to minimize contamination by nonparenchymal cells. The cell viability was tested by trypan blue exclusion $(>90 \%)$. The hepatocytes were plated at a cell density of $10^{5}$ per $16-\mathrm{mm}$ tissue culture dish coated with $250 \mu \mathrm{l}(1: 3 \mathrm{v} / \mathrm{v})$ of Matrigel (laminin, heparan sulfate, type IV collagen) [19]. When cultured on Matrigel, hepatocytes attached rapidly but exhibited minimal spreading (Fig. 1) [19], which was different from the flattened appearance of hepatocytes cultured on plastic. To check the purity of the isolated hepatocytes and to exclude a possibility of toxicity by reagents, total protein secreted by hepatocytes into the media was measured after the method of Bradford, with a Bio-Rad protein assay kit. Throughout the $48-\mathrm{hr}$ experiment, there was no significant difference in protein secretion in presence of dibutyryl-cAMP ( $1 \mathrm{mM})$, IBMX $(0.1 \mathrm{mM}), \mathrm{SS}-14(10$ $\mathrm{n} M)$, and known hepatotrophic factors, such as insulin $(100 \mathrm{ng} / \mathrm{ml})$ or epidermal growth factor (EGF, $100 \mathrm{ng} /$

TABLE 1

Protein Concentration of Media

\begin{tabular}{cc}
\hline Reagents & Protein $(\mu \mathrm{g} / \mathrm{ml})$ \\
\hline Control & $66.7 \pm 1.5$ \\
db-cAMP $(1 \mathrm{mM})$ & $72.4 \pm 10.4$ \\
+ SS-14(10 nM) & $69.6 \pm 1.6$ \\
IBMX $(0.1 \mathrm{mM})$ & $66.3 \pm 2.2$ \\
+ SS-14 & $70.0 \pm 5.5$ \\
Insulin $(100 \mathrm{ng} / \mathrm{ml})$ & $64.5 \pm 6.2$ \\
+ SS-14 & $69.6 \pm 3.1$ \\
EGF $(100 \mathrm{ng} / \mathrm{ml})^{b}$ & $72.0 \pm 10.6$ \\
+ SS-14 & $66.7 \pm 1.8$ \\
\hline
\end{tabular}

Note. Freshly isolated hepatocytes were plated as described under Materials and Methods. After a 24-hr attachment period, media were changed and the appropriate reagents were added. The media were collected $24 \mathrm{hr}$ later, and total protein in the media was measured after the method of Bradford (BioRad, CA). Data are the mean \pm SEM from six dishes in two different experiments.

${ }^{a}$ Dibutyryl-cAMP.

${ }^{b}$ Insulin $(100 \mathrm{ng} / \mathrm{ml})$ was supplemented. 


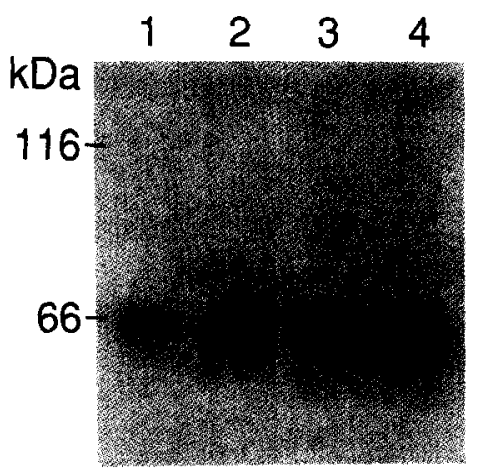

FIG. 2. Immunoblot analysis of secreted albumin into the media by rat hepatocytes. The media ( $25 \mu \mathrm{l})$ from hepatocyte culture dishes treated with appropriate reagents were subjected to electrophoresis (SDS-PAGE) and immunoblot analysis using anti-rat albumin antibodies (Organon Teknica Corp.) [20, 21]. Lane 1, dibutyryl-cAMP (1 $\mathrm{m} M)$; lane 2, dibutyryl-cAMP + SS-14 (10 $\mathrm{nM})$; lane 3, IBMX $(0.1$ $\mathrm{mM}$ ); lane 4, IBMX + SS-14.

$\mathrm{ml}$ ) (Table 1). The presence of secreted albumin in the proteins determined above was also demonstrated by an immunoblot analysis using anti-rat albumin antibodies (Organon Teknica Corp., PA) [20] (Fig. 2). Further, $\left[{ }^{35}\right.$ S $]$ cysteine incorporation into newly secreted albumin into the media was not significantly different among control, insulin $(100 \mathrm{ng} / \mathrm{ml}), \mathrm{SS}-14(10 \mathrm{nM})$, and insulin + SS-14 treated hepatocytes [21], thus confirming viability of hepatocytes treated with SS-14 and/or with other reagents.

\section{Estimation of DNA Synthesis}

DNA synthesis was estimated by the rate of $\left[{ }^{3} \mathrm{H}\right]$ thymidine incorporation into DNA [22] and by autoradiographic measurement of the number of labeled nuclei.

After a $24-\mathrm{hr}$ attachment period, media were changed and the appropriate reagents were added. $\left[{ }^{3} \mathrm{H}\right]$ thymidine $(\sim 2 \mu \mathrm{Ci} /$ dish) was added $6 \mathrm{hr}$ after change of media. Using Dispase (a neutral protease produced by Bacillus polymyxa) [23] for $2 \mathrm{hr}$ at $37^{\circ} \mathrm{C}$, cells were harvested 24 $\mathrm{hr}$ after medium change. Half of the harvested cells were processed for counting, and the other half were used to determine DNA content. The former half was filtered onto GF/C Whatman filters and rinsed with $1 \mathrm{ml}$ of icecold $15 \%$ trichloroacetic acid (TCA, $\times 2$ ) and with $70 \%$ ethanol $(\times 1)$. Filters were dried and placed in $10 \mathrm{ml}$ of scintillation cocktail (EcoLite) and were counted in a scintillation counter (Beckman LS 6000LL). A modified diphenylamine reaction for desoxypentose was performed to measure DNA content [24]. $\left[{ }^{3} \mathrm{H}\right]$ thymidine incorporation was expressed as $\mathrm{cpm} / \mu \mathrm{g}$ DNA.

The labeling index, i.e., the percentage of total nuclei labeled with $\left[{ }^{3} \mathrm{H}\right]$ thymidine, was measured as follows. After an $18-\mathrm{hr}$ exposure to $\left[{ }^{3} \mathrm{H}\right]$ thymidine $(2 \mu \mathrm{Ci} /$ dish $)$, hepatocytes were washed twice with cold phosphatebuffered saline and fixed in $4 \%$ paraformaldehyde for 10 min, coated with Kodak NTB-3 emulsion, and exposed for 10 days before development in Kodak Dektol. The percentage of morphologically defined hepatocytes with labeled nuclei was determined by phase contrast microscopy.

\section{Cyclic AMP Assay}

Freshly isolated hepatocytes $\left(10^{5} / \mathrm{ml}\right)$ were incubated with the appropriate reagents for $5 \mathrm{~min}$. After the incubation period, the test tubes were placed in an ice-water bath for $10 \mathrm{~min}$, then vortexed gently, and centrifuged at $1800 \mathrm{~g}$ for $10 \mathrm{~min}$ at $4^{\circ} \mathrm{C}$. The pellet was deproteinized with $15 \%$ TCA, ether extracted, and lyophilized. Cyclic AMP levels were measured by competitive protein binding assay using an Amersham kit.

\section{Statistical Analysis}

All values shown represent the mean \pm SEM. Wilcoxon signed rank test was used for comparing group means. The level of significance was established at $P$ $<0.05$.

\section{RESULTS}

\section{Effect of Dibutyryl-cAMP on $\left[{ }^{3} H\right]$ Thymidine Incorporation}

As shown in Fig. 3, there was dose-dependent stimulation of $\left[{ }^{3} \mathrm{H}\right]$ thymidine incorporation by dibutyryl-cAMP $\left(10^{-7}\right.$ to $\left.10^{-3} M\right)$. The $1 \mathrm{mM}$ dose was most effective and hence used for the remaining experiments.

\section{Effect of SS-14 on Dibutyryl-cAMP-Stimulated DNA Synthesis}

Addition of dibutyryl-cAMP ( $1 \mathrm{mM}$ ) resulted in a $252 \%$ increase in $\left[{ }^{3} \mathrm{H}\right]$ thymidine incorporation compared to controls. SS-14 (10 $\mathrm{nM})$ significantly inhibited this stimulation (Fig. 4). Of the tested doses (0.1 to 10 $\mathrm{n} M$ ), $10 \mathrm{nM}$ of SS-14 was most effective. We thus used

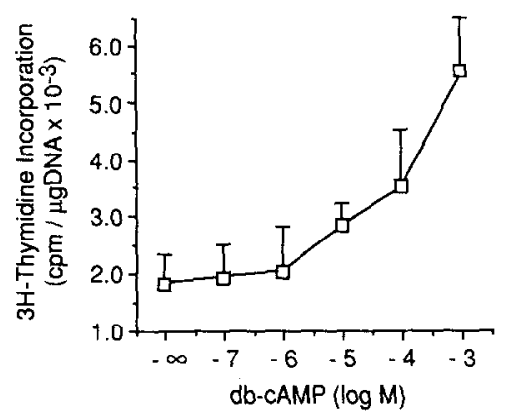

FIG. 3. Dose-dependent stimulation of $\left[{ }^{3} \mathrm{H}\right]$ thymidine incorporation by dibutyryl-cAMP (db-cAMP). Freshly isolated hepatocytes were plated as described under Materials and Methods. After a 24-hr attachment period, media were changed and dibutyryl-cAMP $\left(10^{-7}\right.$ to $\left.10^{-3} \mathrm{M}\right)$ was added. $\left[{ }^{3} \mathrm{H}\right]$ thymidine incorporation into DNA was measured after an 18 -hr exposure to $\left[{ }^{3} \mathrm{H}\right]$ thymidine $(\sim 2 \mu \mathrm{Ci} / \mathrm{dish})$. Points, means of six to eight determinations; bars, SEM. 


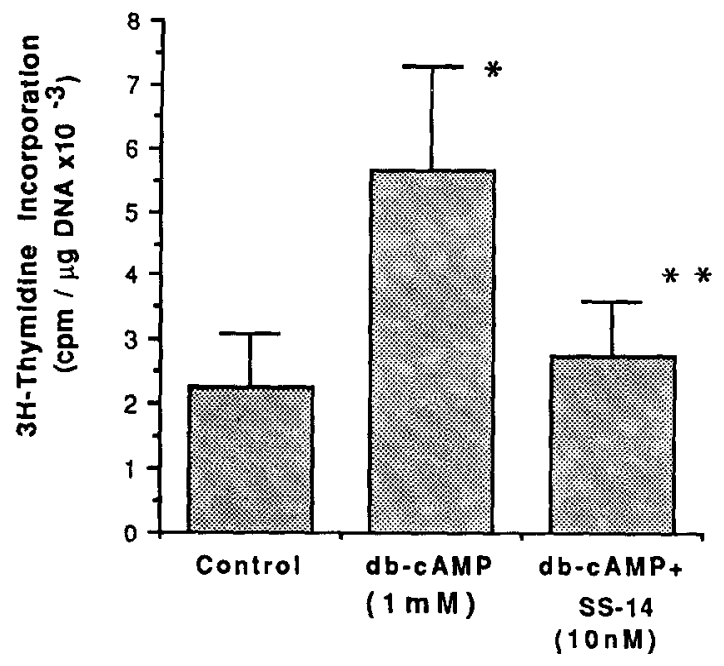

FIG. 4. Fffect of SS-14 (10 $\mathrm{nM})$ on dibutyryl-cAMP (1 $\mathrm{mM})$-stimulated $\left[{ }^{3} \mathrm{H}\right]$ thymidine incorporation. Methods for determining $\left[{ }^{3} \mathrm{H}\right]$ thymidine incorporation were as for Fig. 2. Columns, means from 11-12 dishes from three different experiments; bars, SEM.

${ }^{*} P<0.05$ vs control, ${ }^{* *} P<0.05$ vs dibutyryl-cAMP-stimulated $\left[{ }^{3} \mathrm{H}\right]$ thymidine incorporation.

this dose of SS-14 in this study. Dibutyryl-cAMP also increased labeling index of hepatocytes, which was significantly inhibited by SS-14 (Table 2).

\section{Effects of SS-14 on IBMX-Stimulated DNA Synthesis and Intracellular cAMP}

Preliminary experiments showed that $0.1 \mathrm{mM}$ IBMX was most effective in stimulation of $\left[{ }^{3} \mathrm{H}\right]$ thymidine incorporation. IBMX $(0.1 \mathrm{mM})$-stimulated $\left[{ }^{3} \mathrm{H}\right]$ thymidine incorporation and labeling index were inhibited by $10 \mathrm{n} M$ SS-14 (Table 2, Fig. 5). To investigate the mechanism of this inhibitory effects, we measured the change of intracellular cAMP of rat hepatocytes. Intracellular cAMP

TABLE 2

\begin{tabular}{cc}
$\begin{array}{c}\text { Effect of SS-14 on Dibutyryl-cAMP (db-cAMP)- } \\
\text { and IBMX-stimulated Labeling Index }\end{array}$ \\
\hline Reagents & Labeling index (\%) \\
\hline Control & $12.3 \pm 2.4$ \\
db-cAMP $(1 \mathrm{mM})$ & $35.4 \pm 5.6^{*}$ \\
+ SS-14 $(10 \mathrm{nM})$ & $9.1 \pm 4.4^{* *}$ \\
IBMX $(0.1 \mathrm{mM})$ & $37.5 \pm 5.6^{*}$ \\
+ SS-14 & $11.3 \pm 4.4^{* *}$ \\
\hline
\end{tabular}

Note. The labeling index, i.e., the percentage of nuclei with $\left[{ }^{3} \mathrm{H}\right]$ thymidine, was measured as described under Materials and Methods. Data are the mean \pm SEM from 7-10 determinations from two different experiments.

${ }^{*} P<0.01$ vs control.

** $P<0.01$ vs db-cAMP-or IBMX-stimulated labeling index.

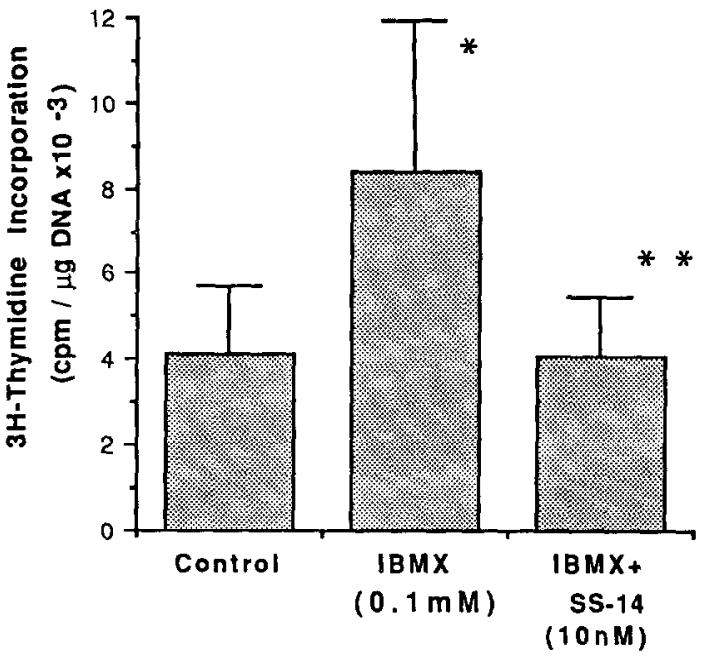

FIG. 5. Effect of SS-14 (10 $\mathrm{nM})$ on IBMX $(0.1 \mathrm{mM})$-stimulated $\left[{ }^{3} \mathrm{H}\right]$ thymidine incorporation. Columns, means from $11-12$ dishes from three different experiments; bars, SEM.

${ }^{*} P<0.05$ vs control, ${ }^{* *} P<0.05$ vs IBMX-stimulated $\left[{ }^{3} \mathrm{H}\right]$ thymidine incorporation.

was significantly increased by IBMX $(0.1 \mathrm{mM})$ and this response was inhibited by $10 \mathrm{nM}$ SS-14 (Fig. 6).

\section{DISCUSSION}

We have shown that dibutyryl-cAMP (a nonhydrolyzable analog of cAMP) and IBMX (an inhibitor of cAMP phosphodiesterase), both of which may increase intracellular cAMP, stimulate hepatocyte DNA synthesis.

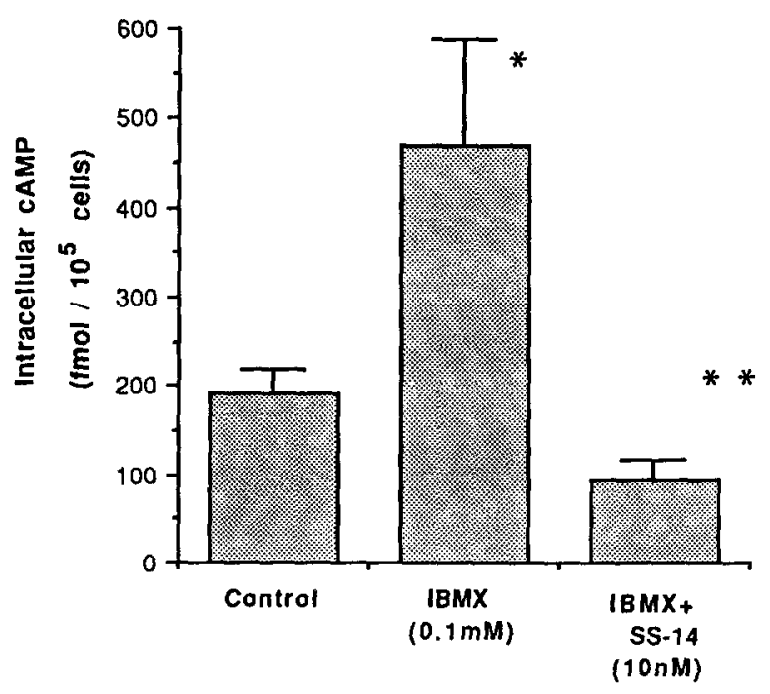

FIG. 6. Effect of SS-14 $(10 \mathrm{nM})$ on IBMX $(0.1 \mathrm{mM})$-stimulated intracellular cAMP accumulation. Conditions for isolation and cAMP assay were as described under Materials and Methods. Columns, means from six tubes from two different experiments; bars, SEM.

${ }^{*} P<0.05$ vs control; ${ }^{* *} P<0.05$ vs $I B M X$-stimulated cAMP accumulation. 
Our system is different from previous studies [25-27] because we did not add any hormones or serum and we coated the culture plates with Matrigel. Using only cAMP-enhancing agents, we were able to exclude the effect of hormones or serum (including unknown factors), which may alter the adenylate cyclase activity. Thus our system was free from any endocrine stimulation. And hepatocytes were still functioning in our system as evidenced by the presence of secreted albumin. Matrigel is the first complete multicomponent preparation of natural solubilized tissue basement membrane. This laminin-rich gel is known to support differentiated functions of cultured hepatocytes for at least 3 weeks [19].

Cyclic AMP is known as one of the intracellular signals which initiate hepatocyte proliferation after partial hepatectomy [28]. Several lines of evidence obtained in studies on cultured hepatocytes [25-27] indicate that cAMP acts in the liver as a growth-promoting agent. Although there are no well-documented experiments showing physiological doses of cAMP, in vitro studies using dibutyryl-cAMP have documented that concentrations between 0.1 and $1 \mathrm{~m} M$ are effective for stimulation [25, 29-31]. Since our studies showed that dibutyryl-cAMP was most effective at $1 \mathrm{mM}$, we used this concentration to stimulate hepatocytes.

SS-14 (10 $\mathrm{n} M)$ significantly inhibited DNA synthesis of rat hepatocytes stimulated by both dibutyryl-cAMP and IBMX. IBMX-stimulated intracellular cAMP accumulation was inhibited by SS-14, suggesting, in part, dependence on adenylate cyclase for antiproliferative effect of SS-14.

By using cAMP analogues, we could bypass signal transduction from receptor to the production of cAMP. SS-14 is known to inhibit dibutyryl-cAMP-stimulated gastric parietal cell activity (aminopyrine uptake) [29]. Koch reported that SS-14 inhibited 8-Br-cAMP (another cAMP analogue)-stimulated prolactin release from pituitary cells [13]. In our study, using rat hepatocytes, SS-14 significantly inhibited dibutyryl-cAMPstimulated $\left[{ }^{3} \mathrm{H}\right]$ thymidine incorporation. The data suggest that inhibitory actions of SS-14 are both proximal and distal to activation of adenylate cyclase. Similar observations have recently been reported in the growth study using the FRTL5 line of rat thyroid follicular cells [32].

In conclusion, SS-14 may exert at least part of its antiproliferative effect via the adenylate cyclase system. However, we must investigate the possibility that the antiproliferative effect of SS-14 may be mediated via multiple pathways because SS-14 has recently been shown to inhibit DNA synthesis of thyroid follicular cells stimulated by insulin-like growth factor I, which is not dependent on cAMP [32]. Further study on other signal transduction systems may yield more information about mechanisms of hepatocyte growth.

\section{ACKNOWLEDGMENT}

The authors thank Shilpa P. Kothary for excellent technical assistance performed as an independent student summer project.

\section{REFERENCES}

1. Brazeau, P., Vale, W., Burgus, R., et al. Hypothalamic peptide that inhibits the secretion of immunoreactive pituitary growth hormone. Science 179: 77, 1973.

2. Lehy, T., Dubrasquet, $M$., and Bonfils, S. Effect of somatostatin on normal and gastric-stimulated cell proliferation in the gastric and intestinal mucosae of the rat. Digestion 19: 99, 1979.

3. Morriset, J. Somatostatin: A potential antigrowth factor for the exocrine pancreas. Regul. Pep. 10: 11, 1984.

4. Pawlikowski, M., Stepien, H., Kunert-Radek, J. et al. Immunomodulatory action of somatostatin. Ann. NY Acad. Sci. 496: $233,1987$.

5. Mascardo, R. N., and Sherline, P. Somatostatin inhibits rapid centrosomal separation and cell proliferation induced by epidermal growth factor. Endocrinology 111 : 1394, 1982.

6. Reubi, J. G., Horisberger, U., Essed, C. E., et al. Absence of somatostatin receptors in human exocrine pancreatic adenocarcinoma. Gastroenterology 95: 760, 1988.

7. Kvols, L. K., Moertel, C. G., O'Connel, M. J., et al. Treatment of the malignant carcinoid syndrome. Evaluation of a long-acting somatostatin analogue. N. Engl. J. Med. 315: 663, 1988.

8. Raper, S. E., Kothary, P. C., and DelValle, J. Somatostatin binding to rat liver plasma membranes. Gastroenterology 96: A408, 1989.

9. Kothary, P. C., Kokudo, N., DelValle, J., et al. Biochemical characterization of a somatostatin (SRIF) binding protein on rat liver plasma membrane (LPM) and isolated hepatocytes. Digestion 46(Suppl 1): 58, 1990.

10. Raper, S. E., Kothary, P. C., Kokudo, N., et al. The liver plays an important role in the regulation of somatostatin-14 metabolism in the rat. Am. J. Surg. 161 : 184, 1991.

11. Goldman, A. L. Influence of somatostatin on hepatic regeneration in the adult rat. Surg. Forum 29: 402, 1978.

12. Chou, C. K., Ho, L. T., Ting, L. P., et al. Selective suppression of insulin-induced proliferation of cultured human hepatoma cells by somatostatin. J. Clin. Invest. 79: 175, 1987.

13. Koch, B. D., Dorflinger, L. J., and Schonbrunn, A. Pertussis toxin blocks both cyclic AMP-mediated and cyclic AMP-independent actions of somatostatin. J. Biol. Chem. 260: 13138, 1985.

14. Reisine, T., Zhang, Y. L., and Sekura, R. Pertussis toxin treatment blocks the inhibition of somatostatin and increases the stimulation by forskolin of cyclic AMP accumulation and adrenocorticotropin secretion from mouse anterior pituitary tumor cells. J. Pharmacol. Exp. Ther. 232: 275, 1985.

15. Reisine, T. Multiple mechanisms of somatostatin inhibition of adrenocorticotropin release from mouse anterior pituitary tumor cells. Endocrinology 116: 2259, 1985.

16. Limbird, L. E. Receptor linked to inhibition of adenylate cyclase: additional signaling mechanisms. FASEB J. 2: 2686, 1988.

17. Seglen, P. O. Preparation of isolated rat liver cells. Methods Cell Biol. 13: 29, 1976.

18. Gumucio, J. J., May, M., Dvorak, C., et al. The isolation of functionally heterogenous hepatocytes of the proximal and distal half of the liver acinus in the rat. Hepatology 6: 932, 1986.

19. Bissell, D. M., Arenson, D. M., Maher, J. J., et al. Support of cultured hepatocytes by a laminin-rich gel. J. Clin. Invest. 79: 801, 1987.

20. Renat, J., Reiser, J., and Stark, G. R. Transfer of proteins from 
gels to diazobenzyloxymethyl-paper and detection with antisera: A method for studying antibody specificity and antigen structure. Proc. Natl. Acad. Sci. USA 76: 3116, 1979.

21. Raper, S. E., Kothary, P. C., and Kokudo, N. Somatostatin-14 blocks the hepatotrophic effects of insulin in the rat. J. Surg. Res. 50: 386, 1991.

22. MacGowan, J. A., Strain, A. J., and Bucher, N. L. DNA synthesis in primary cultures of adult rat hepatocytes in a defined medium: Effect of epidermal growth factor, insulin, glucagon, and cyclicAMP. J. Cell Physiol. 108: 353, 1981.

23. Matsumura, T., Yamanaka, T., Hashizume, S., et al. Tissue dispersion, cell harvest and fluid suspension culture by the use of bacterial neutral protease. Jpn. J. Exp. Med. 45: 377, 1975.

24. Volkin, E., and Cohn, W. E. Estimation of nucleic acids. Methods Biochem. Anal. 1: 287, 1956.

25. Armato, U., Draghi, E., Andreis, P. G., et al. Stimulation by $\mathrm{N}^{6}, \mathrm{O}^{2}$-dibutyryl adenosine $3^{\prime}, 5^{\prime}$-cyclic monophosphate of RNA and DNA synthesis and of cell proliferation of rat hepatocytes in primary tissue culture. J. Cell Physiol. 89: 157, 1976.

26. Hasegawa, K., Namai, K., and Koga, M. Induction of DNA syn- thesis in adult rat hepatocytes cultured in a serum-free medium. Biochem. Biophys. Res. Commun. 95: 243, 1980.

27. Friedman, D. L., Claus, T. H., Pilkis, S. J., et al. Hormonal regulation of DNA synthesis in primary cultures of adult rat hepatocytes. Action of glucagon. Exp. Cell Res. 135: 283, 1981.

28. Rixon, R. H., and Whitfield, J. F. The possible cyclic AMP-dependence of an early prereplicative event that determines mitosis in regenerating rat liver. J. Cell Physiol. 124: 397, 1985.

29. Park, J., Chiba, T., and Yamada, T. Mechanisms for direct inhibition of canine gastric parietal cells by somatostatin. J. Biol. Chem. 262: 14,190, 1987.

30. DelValle, J., and Yamada, T. Amino acids and amines stimulate gastrin release from canine antral G-cells via different pathways. J. Clin. Invest. 85: 139, 1990.

31. Ichihara, A., Nakamura, T., and Tanaka, K. Use of hepatocytes in primary culture for biochemical studies on liver functions. Mol. Cell. Biochem. 43: 145, 1982.

32. Tsuzaki, S., and Moses, A.C. Somatostatin inhibits deoxyribonucleic acid synthesis induced by both thyrotropin and insulin-like growth factor-I in FRTL5 cells. Endocrinology 126: 3131, 1990. 